\section{Original Research}

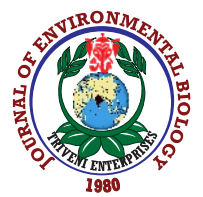

DOI : http://doi.org/10.22438/jeb/41/3/MRN-1111

\title{
Exploration of new effective fibrinolytic agent from Alcaligenes aquatilis PJS_1 from polluted soil
}

\author{
N. Prabhu', K. Sangeetha', C. Jayanthi' and T. Gajendran ${ }^{2 *}$ \\ 'Department of Biotechnology, Vivekanandha College of Engineering for Women, Tiruchengode-637 205, India \\ ${ }^{2}$ Department of Biotechnology, Bharathidasan Institute of Technology, Anna University, Tiruchirappalli-620 024, India \\ *Corresponding Author Email : gajendran01@gmail.com
}

\section{Abstract}

Aim: To isolate and identify Alcaligenes aquatilis PJS_1 from slaughter house soil samples for production of enzymatic fibrinolytic agent production.

Methodology: Fibrinolytic enzyme producing bacterium was isolated from slaughter house soil samples and identified by biochemical tests and $16 \mathrm{~S}$ rRNA sequencing. The fibrinolytic enzyme production media was optimized by various factors like energy sources, $\mathrm{pH}$ and temperature. Bioreactor used in the experiment was designed with suitable parameters for effective production and purification is by gel filtration chromatography. Blood clotting assay was performed to determine its anticoagulant property.

Results: The isolated enzyme producing bacterium was identified as Alcaligenes aquatilis PJS_1. The medium with

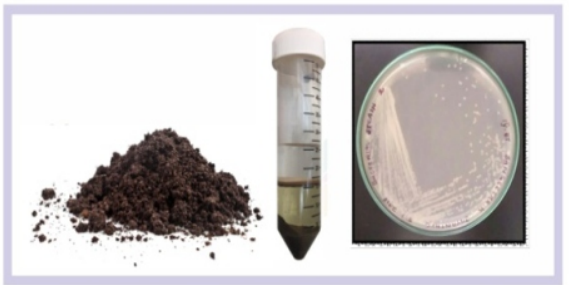

Isolation \& identification of

fibrinolytic enzyme producing bacteria

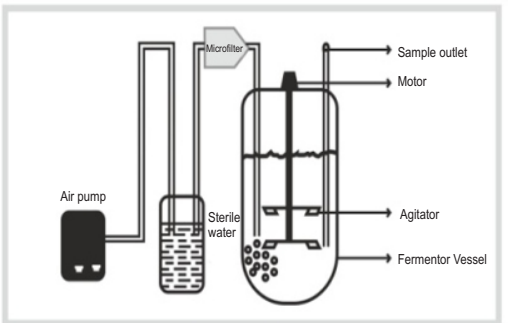

Production of

fibrinolytic enzyme by bioreactor fructose and urea at $\mathrm{pH} 7.0$ was found to have optimum production when incubated for $24 \mathrm{hr}$ at $37^{\circ} \mathrm{C}$. The crude enzyme was purified by acetone precipitation followed by gel filtration chromatography. The enzyme showed a final specific activity of $629.32 \mathrm{Umg}^{-1}$ with of $88.24 \%$ yield.

Interpretation: The present study provides information that the enzyme produced by Alcaligenes aquatilis PJS_1 acts as an effective fibrinolytic agent. Key words: Alcaligenes sp., Anticoagulant, Bioreactor, Fibrinolytic enzyme

How to cite : Prabhu, N., K. Sangeetha, C. Jayanthi and T. Gajendran: Exploration of new effective fibrinolytic agent from Alcaligenes aquatilis PJS_1 from polluted soil. J. Environ. Biol., 41, 572-580 (2020). 


\section{Introduction}

According to clinical report, cardiovascular diseases (CVD) such as acute myocardial infarction, stroke, high blood pressure, ischemic heart disease and arrhythmias are the prominent cause of morbidity and mortality worldwide with 17 million deaths every year (Kapila et al., 2017). In 2011, according to the statistics of the America HeartAssociation, CVD accounted for $31.3 \%$ mortality of Americans (Mozaffarian et al., 2015). Most of the cardiovascular diseases occur due to accumulation of fibrin in the blood vessels which is harmful to human health (Basson 2008). In balanced condition, the fibrin clots are hydrolysed by plasmin to avoid thrombosis in blood vessels (Kannel et al., 1987). Under unbalanced conditions, due to pathophysiological disorders the clots are not hydrolyzed (Arthur, 1998). Deposition of fibrin in blood vessels normally increases thrombosis and other cardiovascular diseases including acute myocardial infarction, high blood pressure, ischemic heart disease, arrhythmias, stroke, etc. In earlier days, thromboembolic vascular diseases were treated using anticoagulants like heparin and warfarin to inhibit the formation of fibrin clots (Bode et al., 1996). However, lysis of preformed fibrin could be accomplished in-vivo by a process involving the conversion of inactive plasminogen to active plasmin enzyme led to an alternative enzyme based approach. Fibrinolytic enzymes convert plasminogen to plasmin and lyse the clot by breaking down the fibrin (Chang etal., 2000).

Many fibrinolytic agents are available commercially to treat cardio vascular diseases.Some of the commonly used agents are, prourokinase, urokinase, streptokinase, reteplase ( $r$ PA), alteplase (t-PA) etc., (Brogden et al., 1973; Kapila et al., 2017). These fibrinolytic agents have many disadvantages such as high cost, need of usage in high clinical dose, low specificity to dissolve the fibrin clot, re-occlusion, less half-life, problems with bleeding issues and sensitive or allergic side effects. Efforts are being made to improve the efficiency, efficacy and specific nature of fibrinolytic treatment. Different sources have been employed for the production of fibrinolytic enzymes that ranges from microorganisms (Ju et al., 2012), plants (Chung et al., 2010) to animals (Huang et al., 2012). Fibrinolytic enzymes from microbes are the most potent and also a cheaper source of protein (Collen and Lijnen, 2004). Because of their greater range of diversity, culture conditions, adaptability to different environments, microbial fibrinolytic enzymes capture much more attention in the red biotechnology (Peng et al., 2005; Bajaj and Sharma 2011). Microbial strains that belong to genus Bacillus, Fusarium, Staphylococcus, Streptomyces and Pseudomonas have been found to produce fibrinolytic enzymes (Choi et al., 2009; Simkhada et al., 2010). Serralysin or Serrapeptidase is a metalloprotease isolated originally from the intestine of silkworm Bombyx mori (Bhargavi and Prakasham, 2012). The homologue of serrapeptidase enzyme, a metalloprotease obtained from Bombyx mori (silk worm) was also reported from microbes such as Pseudomonas aeruginosa, Erwinia chrysanthemi (Bhargavi and Prakasham 2012; Wu et al., 2016) and Deinococcus radiodurans (Basu and Apte, 2008). This enzyme exhibits fibrinolytic activity as well as other medicinal properties such as anti-analgesic and anti-inflammatory function. Hence, it can also be used to treat cardiovascular diseases (Bhargavi and Prakasham, 2013). The present study aimed to isolate, identify and characterize the microorganisms from soil of slaughter house. The production, purification and anticoagulant property of fibrinolytic enzyme were also assessed.

\section{Materials and Methods}

Isolation, screening and identification of fibrinolytic enzyme producing bacteria: Soil samples were collected from different slaughter houses located in Karur district of Tamil Nadu, India. After serial dilution, the soil samples of $10^{-6}$ dilution were spread on nutrient agar plates using L-rod. The isolated colonies were streaked on blood agar plates to check their fibrinolytic activity. All plates were incubated at $37^{\circ} \mathrm{C}$ for $24 \mathrm{hr}$ and a total of 10 positive isolates were obtained. The strains were further screened for casein hydrolysis (Gopinath and Lingappa, 2016) and fibrin hydrolysis described by Astrup and Mullertz (1952). The strain which showed maximum zone in both casein and fibrin was selected for further studies as described by Kim et al. (2006). The colony was grown on nutrient agar plates repeatedly and stored at $4^{\circ} \mathrm{C}$. The strain was biochemically characterized and identified based on 16S rRNA sequence analysis as described by Mahajan et al. (2012). A sequence similarity search was performed using BLAST database in NCBI which showed $99 \%$ similarity with Alcaligenes aquatilis. A phylogenetic tree was constructed using clustal W software to identify its closest relatives. The partial $16 \mathrm{~S}$ rRNA sequence of the strain was submitted to Gene Bank database and assigned accession number MG952633.

Production of fibrinolytic enzyme: The bacterial inoculum was prepared with the help of Luria-Bertani broth medium. The overnight culture was inoculated in $100 \mathrm{ml}$ of production medium consisting of soya peptone, $\mathrm{K}_{2} \mathrm{HPO}_{4}, \mathrm{MgSO}_{4}$, maltose, yeast extract and glucose. The production media was subjected to rotary shaker for $48 \mathrm{hr}$ at $37^{\circ} \mathrm{C}$ for enzyme production. The production medium was centrifuged at 7,000 rpm for $10 \mathrm{~min}$ and the supernatant was used as crude enzyme.

Parameter optimization studies: The production of fibrinolytic enzyme depends on several process parameters. These parameters vary for different microbial strains employed for the production and, hence, parameters such as incubation time, $\mathrm{pH}$, temperature, carbon, nitrogen and inorganic salts have been optimized to ensure maximum enzyme production. The production media was inoculated with $1 \mathrm{ml}$ culture and incubated at different time intervals ranging from $24 \mathrm{hr}$ to $120 \mathrm{hr}$. The effect of various carbon sources such as glucose, sucrose, maltose, fructose, lactose and starch at $1 \%$ concentration were assessed in the production medium. Various nitrogen sources such as beef extract, yeast extract, urea, ammonium chloride, ammonium carbonate and sodium nitrate at $0.5 \%$ were used. In addition, the effect of various inorganic salts such as as $\mathrm{CaCl}_{2}$, $\mathrm{MgSO}_{4}, \mathrm{FeSO}_{4}, \mathrm{Na}_{2} \mathrm{HPO}_{4}, \mathrm{NaH}_{2} \mathrm{PO}_{4}$ and $\left(\mathrm{NH}_{4}\right)_{2} \mathrm{SO}_{4}$ at $0.1 \%$ were 
also assessed. The effect of temperature was studied at $20^{\circ} \mathrm{C}$, $25^{\circ} \mathrm{C}, 30^{\circ} \mathrm{C}, 35^{\circ} \mathrm{C}, 40^{\circ} \mathrm{C}$ and $45^{\circ} \mathrm{C}$. Similarly, the effect of $\mathrm{pH}$ on fibrinolytic enzyme production was investigated by varying the $\mathrm{pH}$ of the medium to $\mathrm{pH} 4.0,5.0,6.0,7.0,8.0$ and 9.0 using $\mathrm{HCl}$ and $\mathrm{NaOH}$. A50 ml of the culture medium in a $250 \mathrm{ml}$ Erlenmeyer flask was incubated aerobically on a rotary shaker (120 rpm). At the end of the cultivation, the crude enzyme was obtained by centrifugation at $7,000 \mathrm{rpm}$ at $4^{\circ} \mathrm{C}$ for $10 \mathrm{~min}$. Activities of the enzyme were determined by standard enzyme assay.

Bioreactor designing and production of fibrinolytic enzyme: The bioreactor was designed with certain parameters like agitation, oxygen sparger, etc., suitable for bacterial cultivation. Designed bioreactor was made up of glass of 5 I capacity. The working volume was 3 I. Flat blade impeller made of Teflon was attached to a shaft made of glass. It was fitted with a motor for agitation. Fish tank sparger was used for aeration inside the reactor. The air was filtered using a $0.22 \mu \mathrm{m}$ filter before letting inside the reactor (Fig. 4). The reactor was filled with 3 I of optimized medium by response surface methodology. The vessel was tightly sealed and ex-situ sterilization was carried out and reactor was allowed to cool at room temperature. The percentage of inoculum added was $1 \%$ from the mother culture of $100 \mathrm{ml}$. The process was carried out under optimum condition, i.e., room temperature and agitation speed of $120 \mathrm{rpm}$ in the presence of $\mathrm{O}_{2}$. Samples were collected periodically using sample outlet every $24 \mathrm{hr}$.

Enzyme assay: Enzyme activity was determined using casein as substrate. One $\mathrm{ml}$ of casein ( $1 \% \mathrm{w} / \mathrm{v}$ in $0.1 \mathrm{M}$ sodium phosphate buffer, $\mathrm{pH} 7$ ) was added to $1 \mathrm{ml}$ of enzyme and incubated for 10 min at room temperature. The reaction was terminated by adding $3 \mathrm{ml}$ of $5 \%$ trichloroacetic acid reagent, kept at room temperature for $30 \mathrm{~min}$ and centrifuged at 7,000 rpm for $10 \mathrm{~min}$. A $0.5 \mathrm{ml}$ of Folin- Ciocalteau reagent (1:2 dilutions) was added to the supernatant and the absorbance was measured at $660 \mathrm{~nm}$. One unit of enzyme activity $(U)$ was defined as the amount of enzyme required to liberate 1 microgram of tyrosine per min under the defined assay conditions. The range of $20-100 \mu$ g of tyrosine was used as standard.

Protein assay: The total protein content of the samples was determined by the method of Lowry et al using bovine serum albumin as standard (Lowry et al., 1951).

Partial purification by acetone precipitation: Ice cold acetone was added drop wise using pipette to about $50 \mathrm{ml}$ of the crude enzyme extract and stirred slowly. The enzyme was allowed to precipitate at $4^{\circ} \mathrm{C}$ for $60 \mathrm{~min}$. The precipitated enzyme was centrifuged at $4^{\circ} \mathrm{C}$ using cooling centrifuge at $10,000 \mathrm{rpm}$ for 10 min. The supernatant was carefully discarded. The uncapped centrifuge tubes were kept at room temperature for $30 \mathrm{~min}$ to allow all the acetone to evaporate. The pellets were collected, dissolved in phosphate buffer and stored at $4^{\circ} \mathrm{C}$.

Gel filtration chromatography: Fibrinolytic enzyme was further purified by chromatography on Sephadex G-75. The column was equilibrated with chromatography buffer and the column was calibrated by standard protein sample. The protein fraction was then passed through the column. The protein sample was eluted with a flow rate of $0.5 \mathrm{ml}^{-1} \mathrm{~min}^{-1}$ and the volume of protein eluted was recorded. The fractions collected were determined for total protein concentration and fibrinolytic enzyme activity.

Testing Anticoagulant property: To test the anticoagulant property of the purified enzyme, $200 \mu$ l of enzyme was added to $100 \mathrm{mg}$ of coagulated blood and was incubated at $37^{\circ} \mathrm{C}$ for $2 \mathrm{hr}$ (Collins et al., 1995).

Statistical analyses: The optimum level and multiple regression analysis of different variables affecting the fibrinolytic enzyme

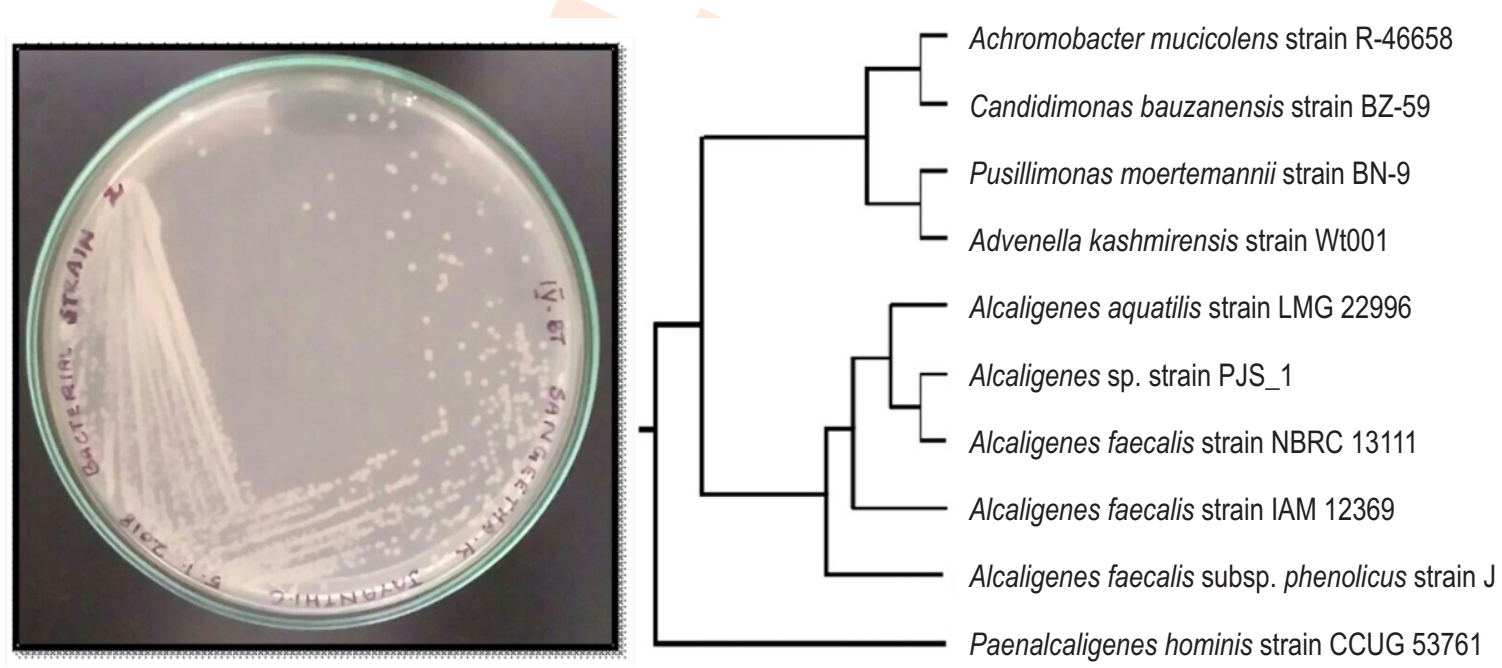

Fig. 1: Phylogenetic relationships of Alcaligenes sp. strain PJS_1 and other closely related species. 


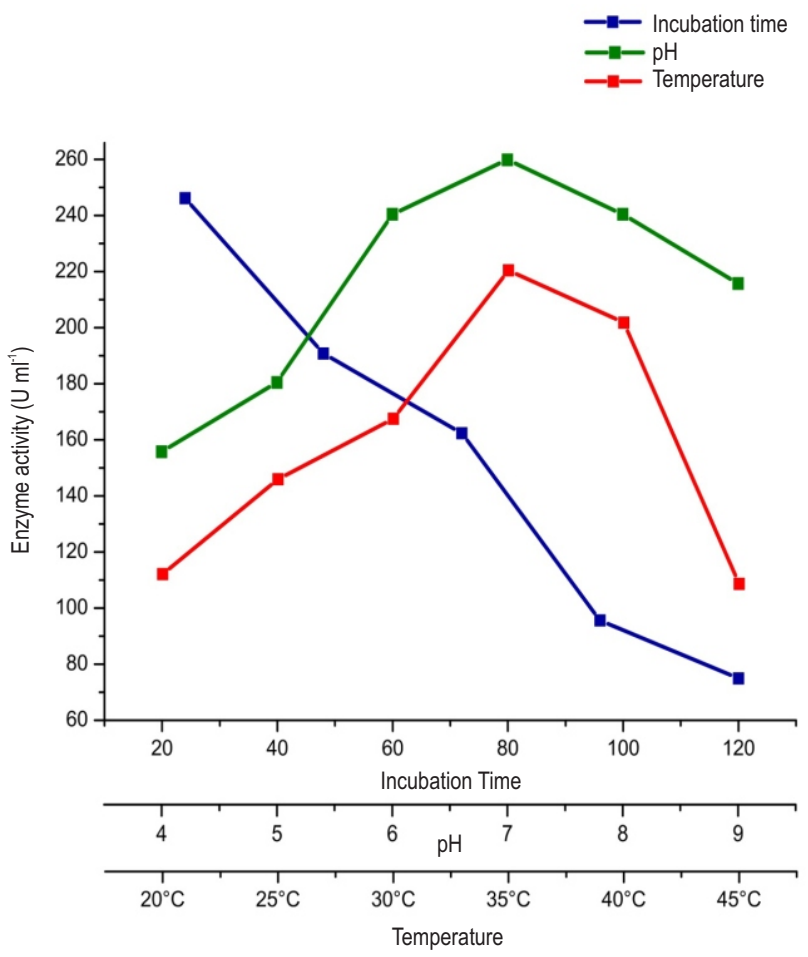

Fig. 2: Fibrinolytic enzyme activity at different temperature $\left({ }^{\circ} \mathrm{C}\right), \mathrm{pH}$ and incubation time (hr)

production was determined by systemic design of different experiments using central composite design (CCD) (Design Expert Software Version 7.0.0, Stat-Ease Inc., Minneapolis, MN, USA). Based on the preliminary studies minimum and maximum level of independent variables, i.e., fructose, urea, ammonium sulphate were selected while other variables were kept constant.

\section{Results and Discussion}

Alcaligenes aquatilis PJS_1 was isolated from contaminated soil samples and was found to be Gram-negative, rod shaped bacterium. The strain was positive for catalase, caseinase, citrate utilization and methyl red and indole production, while it showed negative results for Voges-Proskauer test. Based on 16S rRNA sequence analysis, the strain was phylogenetically characterized and identified the closest relative using BLAST search in NCBI database. The strain identified belonged to family Alcaligenaceae. PJS_1 and showed 99\% sequence similarity with its closest relative Alcaligenes aquatilis, a marine bacterium. A phylogenetic tree showing similarity as distance was constructed for the PJS_1 strain using Clustal W online tool (Fig. 1). Similarly microorganisms including Bacillus cereus NK1 (Venkataraman et al., 2010), Serratia sp. RSPB11 (Bhargavi and Prakasham 2013), Bacillus sp. IND7 (Ponnuswamy et al., 2016), Bacillus amyloliquefaciens (Peng et al., 2003), Serratia sp. KG-2-1 (Kapila et al., 2017), Bacillus

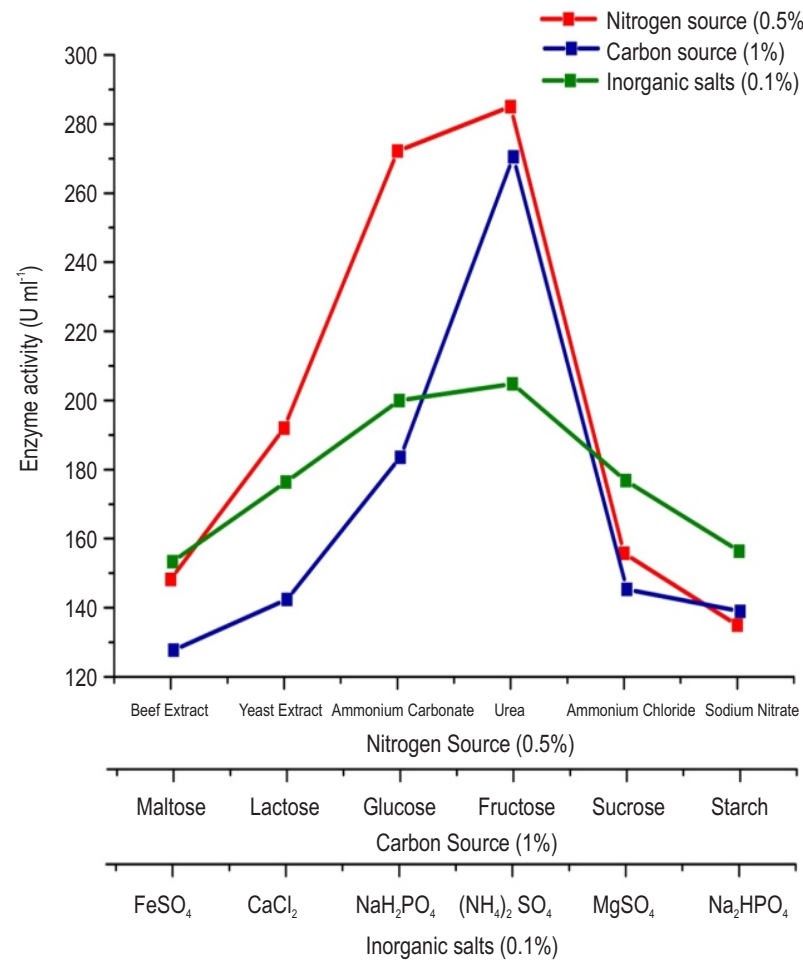

Fig. 3: Fibrinolytic enzyme activity at different nitrogen sources, carbon sources and inorganic salts.

tequilensis (Xiong et al., 2018) and Bacillus pumilus (Afifah et al., 2014) from both land and marine environment have also been reported to produce nattokinase-like fibrinolytic enzymes.

Since different microbes possess diverse physiological characteristics, it is necessary to optimize nutrient components and environmental conditions for cell growth and fibrinolytic enzyme production (Lee et al., 2005). The production media was inoculated and incubated at different time intervals ranging from $24 \mathrm{hr}$ to $120 \mathrm{hr}$ and the enzyme activity was noted every 24 $\mathrm{hr}$. From the results, it was observed that fibrinolytic enzyme production commenced and reached the maximal enzyme activity $\left(246.2 \mathrm{U} \mathrm{ml}^{-1}\right)$ in $24 \mathrm{hr}$ of incubation, continued till $72 \mathrm{hr}$ and decreased thereafter (Fig. 2). For further experiment, the incubation period was maintained at $24 \mathrm{hr}$. The strain PJS_1 had shorter period of incubation time for fibrinolytic enzyme production when compared to earlier reports. As reported in another study on Serratia sp., the ideal incubation time for effective production of enzyme varied from $24 \mathrm{hr}$ to $48 \mathrm{hr}$. (Bhargavi and Prakasham 2012; Kapila et al., 2017). The pH of the medium is one of the most critical environmental parameter affecting the enzyme production and any variation in $\mathrm{pH}$ can change the shape of the active site during high and low $\mathrm{pH}$ concentration resulting in loss of enzyme activity due to denaturation. The optimum $\mathrm{pH}$ for the fibrinolytic activity of Alcaligenes aquatilis PJS_1 was at $\mathrm{pH} 7.0$ with the highest 


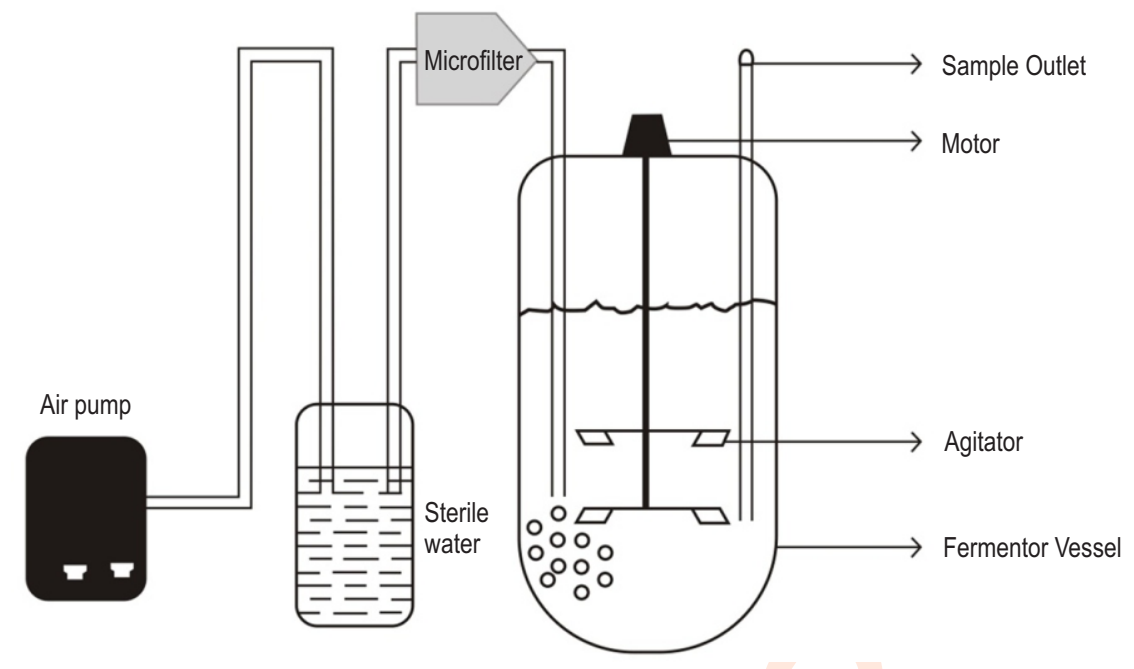

Fig. 4: Design of bioreactor for fibrinolytic enzyme production.

activity of $260 \mathrm{Uml}^{-1}$ (Fig. 2) and the enzyme activity decreased gradually at $\mathrm{pH}$ levels above and below 7.0. The results indicated that the isolated Alcaligenes aquatilis PJS 1 produces fibrinolytic enzymes at neutral $\mathrm{pH}$. Fibrinolytic enzymes belonging to serine proteases are generally active at neutral and alkaline $\mathrm{pH}$, with optimum $\mathrm{pH}$ ranging between 8-10 (Ko et al., 2004). It is also reported that the, maximum enzyme production in Serratia sp. occurs between pH 7-8 (Kapila et al., 2017). The $\mathrm{pH}$ dependent enzyme production has been studied in different strains with optimal pH ranging from 5 to 10 (Kim and Choi, 2000; Kim et al., 2011).

The incubation temperature is the next most crucial factor that has to be optimized for enzyme production. All enzymes have an optimal temperature at which the reaction rates increases without denaturing the enzyme. The optimal temperature for synthesis of microbial fibrinolytic enzyme has a wide range, between 30 and mostly about $50^{\circ} \mathrm{C}$ (Yong Peng et al., 2003). In case of PJS_1, the enzyme activity increased with the increase in temperature from $20-35^{\circ} \mathrm{C}$ and decreased above $35^{\circ} \mathrm{C}$. The maximum fibrinolytic enzyme production was obtained at $35^{\circ} \mathrm{C}$ $\left(220.4 \mathrm{U} \mathrm{ml}^{-1}\right)$ whereas the least production was observed at $20^{\circ} \mathrm{C}$ (112.1 $\mathrm{U} \mathrm{ml}^{-1}$ ) under $24 \mathrm{hr}$ incubation (Fig. 2). Studies on Serratia sp. RSPB11 strain have showed that the optimal temperature is $32^{\circ} \mathrm{C}$, while that of strain DT3 is $28^{\circ} \mathrm{C}$, and for Marcescens sp. it was found to be $40^{\circ} \mathrm{C}$ (Bhargavi and Prakasham, 2012). Cumulatively in most organisms the optimum temperature ranges between $30^{\circ} \mathrm{C}$ to $85^{\circ} \mathrm{C}$ as reported in many experiments experiments for microbial enzymes production (Kim and Choi 2000; Choi et al., 2009; Lee et al., 2010; Kim et al., 2011). The medium components play a significant role in enhancing the enzyme production. Different carbon sources were employed to determine the production of extracellular fibrinolytic enzyme after $24 \mathrm{hr}$ of incubation. The PJS_1 strain grew in all media however, the fibrinolytic activity was different in different media, and fructose displayed the best carbon source. Basal activities were found in maltose $\left(127.2 \mathrm{U} \mathrm{ml}^{-1}\right)$, starch $\left(138.4 \mathrm{U} \mathrm{ml}^{-1}\right)$, lactose $\left(141.8 \mathrm{U} \mathrm{ml}^{-1}\right)$, sucrose $\left(144.8 \mathrm{U} \mathrm{ml}^{-1}\right)$ and glucose $\left(183 \mathrm{U} \mathrm{ml}^{-1}\right)$, although the maximal activity was detected in fructose $\left(270 \mathrm{U} \mathrm{ml}^{-1}\right)$ (Fig. 3). An increased yield of fibrinolytic enzyme production from various carbon sources such as lactose (Mukesh kumar et al., 2012), maltose, sucrose (Hmood and Aziz, 2016) have been reported from other resources. It is reported that maltose when used as carbon source was found to maximize the enzyme production i.e., $201.2 \mathrm{U} \mathrm{ml}^{-1}$ followed by other commonly used carbon sources (Kapila et al., 2017).

In most microorganisms, both inorganic and organic forms of nitrogen are metabolized to produce amino acids, proteins, nucleic acids and cell wall components (Saxena and Singh, 2010). The effect of organic (beef extract, yeast extract, urea) and inorganic (ammonium carbonate, ammonium chloride, sodium nitrate) nitrogen sources on fibrinolytic enzyme production by Alcaligenes sp. was investigated. It was noted that among different nitrogen sources, urea $\left(285 \mathrm{U} \mathrm{ml}^{-1}\right)$ was best, followed by ammonium carbonate (272.2 $\left.\mathrm{U} \mathrm{ml}^{-1}\right)$ (Fig. 3). In earlier reports peptone (Mukesh et al., 2012), casein, beef extract were found effective ingredients for enzyme production (Hmood and Aziz, 2016; Venkataraman et al., 2010; Bajaj et al., 2014). In the present study, the inorganic salts $\left(\mathrm{NaH}_{2} \mathrm{PO}_{4}, \mathrm{CaCl}_{2}, \mathrm{MgSO}_{4}\right.$, $\mathrm{Na}_{2} \mathrm{HPO}_{4},\left(\mathrm{NH}_{4}\right)_{2} \mathrm{SO}_{4}$ and $\left.\mathrm{FeSO}_{4}\right)$ were evaluated for the production of fibrinolytic enzyme (Fig. 3). The medium was inoculated with $1 \mathrm{ml}$ inoculum and incubated for $24 \mathrm{hr}$. Interestingly, ammonium sulphate significantly enhanced fibrinolytic enzyme production. In a previous report, $\mathrm{NaH}_{2} \mathrm{PO}_{4}$, $\mathrm{MnCl}_{2}$ (Hmood and Aziz, 2016), $\mathrm{CaCl}_{2}$ (Saxena and Singh, 2010) was found to be the optimum inorganic salts for enzyme production. However, the production of serine protease is 
Table 1: Plackett-Burman Design for fibrinolytic enzyme production

\begin{tabular}{llllllllll}
\hline $\mathbf{R}$ & $\mathbf{I}$ & $\mathrm{pH}$ & $\mathrm{AS}$ & $\mathbf{G}$ & $\mathbf{A C}$ & $\mathrm{NaH}_{2} \mathbf{P O}_{4}$ & $\mathbf{F}$ & $\mathbf{U}$ & $\begin{array}{c}\text { Enzyme } \\
\text { activity } \\
\left(\mathbf{U} \mathrm{ml}^{-1}\right)\end{array}$ \\
\hline 1 & -1 & 1 & -1 & -1 & -1 & 1 & 1 & 1 & 176.4 \\
2 & 1 & -1 & 1 & 1 & -1 & 1 & -1 & -1 & 183.0 \\
3 & -1 & 1 & 1 & 1 & -1 & 1 & 1 & -1 & 192.0 \\
4 & 1 & 1 & 1 & -1 & 1 & 1 & -1 & 1 & 148.2 \\
5 & -1 & 1 & 1 & -1 & 1 & -1 & -1 & -1 & 225.0 \\
6 & 1 & -1 & 1 & -1 & -1 & -1 & 1 & 1 & 204.4 \\
7 & 1 & -1 & -1 & -1 & 1 & 1 & 1 & -1 & 199.6 \\
8 & -1 & -1 & -1 & -1 & -1 & -1 & -1 & -1 & 270.0 \\
9 & 1 & 1 & -1 & 1 & 1 & -1 & 1 & -1 & 155.8 \\
10 & 1 & 1 & -1 & 1 & -1 & -1 & -1 & 1 & 95.6 \\
11 & -1 & -1 & 1 & 1 & 1 & -1 & 1 & 1 & 216.0 \\
12 & -1 & -1 & -1 & 1 & 1 & 1 & -1 & 1 & 75.0 \\
\hline
\end{tabular}

R- Run order; I- Incubation time; AS- Ammonium Sulphate; G- Glucose; AC- Ammonium Carbonate; F- Fructose; U- Urea

Table 2: Experimental design and results of the Central Composite Design

\begin{tabular}{lllll}
\hline $\begin{array}{l}\text { Run } \\
\text { order }\end{array}$ & Fructose & Urea & $\begin{array}{l}\text { Ammonium } \\
\text { sulphate }\end{array}$ & $\begin{array}{l}\text { Enzyme } \\
\text { activity }\left(\mathrm{U} \mathrm{ml}^{-1}\right)\end{array}$ \\
\hline 1 & 1.681793 & 0 & 0 & 214.9 \\
2 & -1 & 1 & -1 & 199.6 \\
3 & 0 & 0 & 1.681793 & 309.1 \\
4 & 0 & 0 & 0 & 288.7 \\
5 & 0 & -1.68179 & 0 & 356.4 \\
6 & -1 & -1 & 1 & 298.6 \\
7 & 0 & 0 & 0 & 440.3 \\
8 & -1 & -1 & -1 & 415.8 \\
9 & 1 & 1 & 1 & 372.9 \\
10 & 1 & -1 & 1 & 327.4 \\
11 & 0 & 0 & 0 & 216.9 \\
12 & 0 & 0 & 0 & 388.8 \\
13 & 0 & 0 & 0 & 218.6 \\
14 & 1 & -1 & -1 & 429 \\
15 & -1.68179 & 0 & 0 & 448.4 \\
16 & 0 & 0 & -1.68179 & 456.6 \\
17 & 0 & 1.681793 & 0 & 448.2 \\
18 & 0 & 0 & 0 & 449.6 \\
19 & -1 & 1 & 1 & 442.6 \\
20 & 1 & 1 & -1 & 452.45 \\
\hline
\end{tabular}

dependent on the concentration of metal ions due to feedback inhibition during translocation across the plasma membrane (Mahajan et al., 2012). Statistical approaches like PlacketBurman and Response Surface Methodology are highly successful and preferred for optimization, increasing enzyme production.

The requirement of media and condition varies largely by species and cannot be generalized. The enzyme yield also varies between strains and was optimized. Plackett-Burman design identifies important variables and ranks them in the order of their importance, so that one can decide the investigation of the most important variable in a more detailed study, thereby the optimum values to use could be determined (Srinivas et al., 1994). The design matrix consists of 12 experimental runs and the corresponding responses of fibrinolytic activity are shown in Table 1. These responses were analysed using minitab pro 16.1.1.0. The results showed that fructose, urea and ammonium sulphate had positive effect on enzyme production. On the other hand, Tamura et al. (2007) reported that incubation time, pH, $\mathrm{NaH}_{2} \mathrm{PO}_{4}$, glucose and ammonium carbonate has negative effect on the activity of enzyme obtained from pareto chart from the pareto chart (Fig. 5) as shown below, major screening variables fructose, urea and ammonium sulphate were selected for further optimization using RSM to obtain optimum medium concentration. Saravana kumar et al. (2010) demonstrated that the use of central composite factorial design showed fine result for high yield extracellular alkaline protease production from

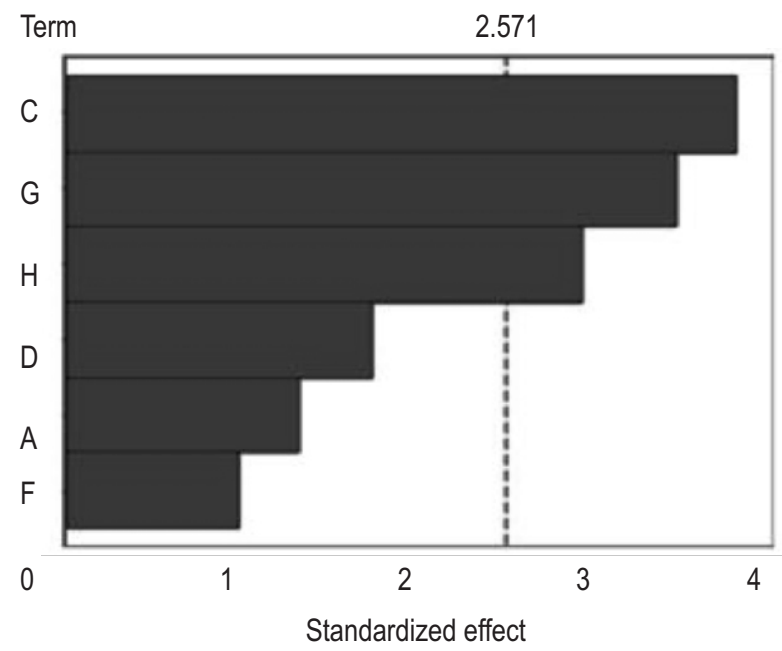

Fig. 5: : Pareto chart standardized effects (response is enzyme activity, $\alpha=0.05)$. A: Incubation time; $B$ : pH; C: Ammonium sulphate; D: Glucose; $\mathrm{E}:$ Ammonium carbonate; $\mathrm{F}: \mathrm{NaH}_{2} \mathrm{PO}_{4} ; \mathrm{G}$ : Fructose; $\mathrm{H}$ : Urea. 
Table 3: Results of regression analysis of Central Composite Rotatory Design

\begin{tabular}{|c|c|c|c|c|c|c|}
\hline Source & Sum of square & Df & Mean Square & F Value & P-value Prob> F & \\
\hline Model & 163214.9 & 9 & 18223.88 & 527.4532 & $<0.0001$ & \multirow{10}{*}{ Significant } \\
\hline A-Fructose & 2772.246 & 1 & 2792.2446 & 80.97074 & $<0.0001$ & \\
\hline B-Urea & 33159.21 & 1 & 33459.21 & 967.9314 & $<0.0001$ & \\
\hline C-Ammonium sulphate & 53290.33 & 1 & 53280.33 & 1550.89 & $<0.0001$ & \\
\hline$A B$ & 94.6001 & 1 & 91.6001 & 2.753112 & 0.1281 & \\
\hline$A C$ & 277.8903 & 1 & 276.8903 & 8.087346 & 0.0174 & \\
\hline $\mathrm{BC}$ & 41.63281 & 1 & 41.63281 & 1.211625 & 0.2968 & \\
\hline$A^{2}$ & 18391.5 & 1 & 18291.5 & 535.2416 & $<0.0001$ & \\
\hline$B^{2}$ & 39632.7 & 1 & 39532.7 & 1153.417 & $<0.0001$ & \\
\hline$C^{2}$ & 29246.1 & 1 & 29146.1 & 851.1393 & $<0.0001$ & \\
\hline Residual & 343.6112 & 10 & 34.35112 & - & - & \multirow{4}{*}{$\begin{array}{c}\text { Not } \\
\text { significant }\end{array}$} \\
\hline Lack of Fit & 232.8798 & 5 & 46. 96595 & & & \\
\hline Pure Error & 108.7315 & 5 & 21.6463 & 2.160182 & 0.2089 & \\
\hline Cor Total & 163458.6 & 19 & - & & & \\
\hline
\end{tabular}

Aspergillus fischeri. Similarly, Rajesh et al. (2016) reported that keratinase enzyme was produced from Bacillus cereus with the help of RSM.

RSM is a powerful technique for testing multiple process variables, because fewer experimental trials are required when compared with the study of one variable at a time. Also, interaction between variables can be identified and quantified by this technique. The significant factors (fructose, urea, ammonium sulphate) were investigated further using CCD. Using CCD, 20 experiments were carried out with various combinations of three independent variables and corresponding responses of fibrinolytic activity are shown in Table 2 . The graphs were plotted on the basis of model equation to determine the interaction among the variables. Vijayaraghavan and Vincet (2014) reported that fibrinolytic enzyme produced from Pseudomonas sp. IND11 increased three-fold through the optimization of various factors supplemented with cow dung using response surface methodology. Holmstrom and Kjelleberg (1999) demonstrated that studies related to optimized production of fibrinolytic enzyme from Pseudomonas sp. gives better idea for production of other bioactive compounds. ANOVA of the optimization study is given in Table 3. The Model F-value of 527.45 implies that the model was significant (Khataee et al., 2010). The model was highly significant and sufficient to represent the actual relationship between the response and significant variables as indicated by small model P-value (<0.0001), large lack-of-fit P-value (0.2089) (Hymavathi et al., 2010). The "Lack of Fit F-value" of 2.16 implies that it was non-significant relative to pure error. Non-significant lack of fit was good. Values of "Probability $>F$ " $(0.0500)$ indicate that model terms were significant. In this case, $A, B, C, A C, A^{2}, B^{2}$, $C^{2}$ were significant model terms. The regression equation coefficient was calculated and the data were fitted into a secondorder polynomial equation as given below:

Enzyme activity $=+232.44599+6.07417 \mathrm{~A}-6.49029 \mathrm{~B}+$ $11.52256 \mathrm{C}+1.62500 \mathrm{AB}+8.62500 \mathrm{AC}-4.37500 \mathrm{BC}-15.14270 \mathrm{~A}^{2}$ $-25.21897 B^{2}-4.00577 C^{2}$

where, $A$ is fructose, $B$ is urea and $C$ is ammonium sulphate
Response surface methodology has been successfully enhancing used for fibrinolytic enzyme production by Bacillus natto, Bacillus subtilis and Bacillus sp. strain AS-S20-1 (Mukesh kumar et al., 2012). Coninck et al. (2004) illustrated that experimental design shows the best graphical representation for response of different operational variable interactions. This study demonstrated application of a multifactorial statistical approach for determining suitable fermentation conditions for maximum yield of fibrinolytic enzyme from a newly isolated strain such as Alcaligenes aquatilis PJS_1. Overnight culture of Alcaligenes aquatilis PJS_1 in the reactor showed good growth, indicating that the designed parameters provide optimum condition to the process (Fig. 4). By applying response surface methodology, in fibrinolytic enzyme production by Alcaligenes aquatilis PJS_1, optimum amount of $\mathrm{pH}(\mathrm{pH} 7)$, agitation, incubation time (24 hr), temperature $\left(35^{\circ} \mathrm{C}\right)$, carbon source (fructose), nitrogen source (urea) and inorganic salts $\left(\left(\mathrm{NH}_{4}\right)_{2} \mathrm{SO}_{4}\right)$ are found as positive factors playing significant role. Response surface curves from response surface are helpful in visualizing the main effects and interaction of various factors (Eldeen et al., 2015). The optimum culture medium obtained from this experiment gives primary information for further study with batch or fed-batch cultivation in a bioreactor for large scale production of target metabolite such as fibrinolytic enzyme from Alcaligenes aquatilis PJS_1.

The fibrinolytic enzyme was purified by acetone precipitation and chromatography techniques. Acetone is volatile and is generally used for precipitation and easily evaporates after precipitation. The extract was first subjected to acetone precipitation, and the active fractions were obtained. The fibrinolytic enzyme was purified 1.06 fold with $85.3 \%$ yield by acetone precipitation technique. The specific activity of final enzyme preparation was $564.05 \mathrm{U} \mathrm{mg}^{-1}$ by precipitation method. The active fractions were further separated via gel filtration chromatography on sephadex G-75. The enzyme was purified 1.1 fold with $88.24 \%$ yield following these purification steps. The specific activity of final enzyme was estimated to be $629.32 \mathrm{U} \mathrm{mg}$ 
1. Finally, the anticoagulant property was checked by using this purified fibrinolytic enzyme. Previous studies have shown that almost all fibrinolytic enzymes obtained from various microbial sources were collected in a pure form through protein precipitation method by using ammonium sulphate or ethanol followed by dialysis and chromatography techniques.

It resulted in the yield of 6.5-95.0\% pure form of enzyme with $4.9-56 \%$ fold purification (Mahajan et al., 2012). Lee et al. (2010) reported that fibrinolytic protease produced from Bacillus amyloliquefaciens Ch86-1 and the so obtained pure form using ammonium sulfate precipitation followed by CMSephadex and Phenyl Sepharose column chromatography yielded enzyme with $100.2 \mathrm{U} \mathrm{mg}^{-1}$ specific activity, $1.22 \%$ recovery and purification folds of 25.96 times. Anti-coagulant property can be determined when the enzyme is allowed to dissolve the coagulated blood in suitable incubation time with specific $\mathrm{pH}$ and temperature. It is the easiest and preliminary step to check anticoagulant nature of any fibrinolytic enzyme extracted from microbes through this method (Collins et al., 1995).

The investigation of a microbial species for the production of fibrinolytic enzyme with optimal conditions provided has been done. The produced enzyme was tested for its anticoagulant property and found to be effective. All these preliminary characterization suggested that Alcaligenes sp. have potential fibrinolytic activity and can be a useful tool in preventive medicine after wide research.

\section{Acknowledgment}

The authors are grateful to the Management and Staffs of Vivekanandha Group of Institutions, Tiruchengode, Tamil Nadu, India for providing necessary facilities to carry out this work.

\section{References}

Afifah, D.N., M. Sulchan and D. Syah: Purification and characterization of a fibrinolytic enzyme from Bacillus pumilus 2 isolated from gembus, an Indonesian fermented food. Prev. Nutr. Food Sci.,19, 213-219(2014).

Arthur, A.S.: Urokinase: Past, Present and Future. Tech. Vasc. Inter. Radiol., 1, 170-178(1998).

Astrup, T. and S. Mullertz: The fibrin plate method for estimating fibrinolytic activity. Arch. Biochem., 40, 346-351(1952).

Basu, B. and S.K. Apte: A novel serralysin metallo protease from Deinococcus radiodurans. Biochem Biophys. Acta., 1784, 1256-1264 (2008)

Bajaj, B.K. and P. Sharma: An alkali-thermotolerant extracellular protease from a newly isolated Streptomyces sp. DP2. New Biotechnol., 28, 725-732 (2011).

Bajaj, B.K., S. Singh, M. Khullar, K. Singh and S. Bhardwaj: Optimization of fibrinolytic protease production from Bacillus subtilis I-2 using agro-residues. Braz. Archives Bio. Technol., 57, 653-662 (2014).

Bhargavi, P.L. and R.S. Prakasham: Proteolytic enzyme production by isolated Serratia sp. RSPB11: Role of environmental parameters. Curr. Trends Biotechnol. Pharm., 6, 55-65(2012).

Bhargavi, P.L. and R.S. Prakasham: A fibrinolytic, alkaline and thermostable metallo protease from the newly isolated Serratia sp.
RSPB11. Int. J Biol. Macromol., 61, 479-486 (2013).

Basson, M: Cardiovascular Disease. Nature, 451, 903 (2008).

Bode, C., M. Runge and R.W. Smalling: The future of thrombolysis in the treatment of acute myocardial infarction. Eur. Heart. J., 17, 55-60 (1996).

Brogden, R.N., T.M. Speight and G.S. Avery: Streptokinase: A review of its clinical pharmacology, mechanism of action and therapeutic uses. Drugs, 5, 357-445 (1973).

Chang, C.T., M.H. Fan, F.C. Kuo and H.Y. Sung: Potent fibrinolytic enzyme from a mutant of Bacillus subtilis IMR-NK1. J. Agric. Food. Chem., 48, 3210-3216 (2000).

Choi, N.S., J.J. Song, D.M. Chung, Y.J. Kim, P.J. Maeng and S.H. Kim: Purification and characterization of a novel thermoacid-stable fibrinolytic enzyme from Staphylococcus sp. strain AJ isolated from Korean salt-fermented Anchovy-joet. J. Ind. Microbiol. Biotechnol., 36, 417-426 (2009)

Chung, D.M., N.S. Choi, H.K. Chun, P.J. Maeng, S.B. Park and S.H. Kim: A new fibrinolytic enzyme (55 kDa) from Allium tuberosum: Purification, characterization and comparison. J. Med. Food, 13, 1532-1536 (2010).

Collen, D. and H.R. Lijnen: Tissue-type plasminogen activator: A histological perspective and personal account. J. Thromb. Haemost., 2, 541-546 (2004).

Collins, C.H. and P.M. Lynee: Microbiological Methods. $7^{\text {th }}$ Edn., Butterworth-Heinemann Ltd. (1995).

Coninck, J.D., B. Leclercq, J.M. Exbrayat and F. Duyme: Factorial designs: An efficient approach to choosing the main factors influencing growth and hydrolase production by Tetrahymena thermophila. J. Ind. Microbiol. Biotechnol., 31, 204-208 (2004).

Eldeen, K.I., H.M. Ibrahim, E.E. Elkhidir and H.B. Elamin: Optimization of culture conditions to enhance nattokinase production using RSM. Am. J. Microbiol. Res., 3, 165-170 (2015).

Gopinath, S.M. and K. Lingappa: Isolation and screening of fibrinolytic enzymes producing bacterium strain from soil waste. Int. J. Curr. Microbiol. App. Sci., 5, 969-976 (2016).

Hmood, S.A. and G.M. Aziz: Optimum conditions for fibrinolytic enzyme (Nattokinase) production by Bacillus sp. B24 using solid state fermentation. Ira. J. Sci., 57, 1391-1401 (2016).

Holmstrom, C. and S. Kjelleberg: Marine Pseudo alteromonas species are associated with higher organisms and produce biologically active extracellular agents. FEMS. Microbiol. Ecol., 30, 285-293 (1999).

Huang, M.X., Y. Ye, Y.X. Chen and Y.L. Han: Partial purification and characterization of fibrinolytic enzymes from yellow mealworm. Int. J. Pept. Res. Ther., 18, 153-161 (2012).

Hymavathi, M., T. Sathish, P. Brahmaiah and R.S. Prakasham: Impact of carbon and nitrogen sources on L-asparaginase production by isolated Bacillus circulans (MTCC 8574): Application of saturated Plackett-Burman Design. Chem. Biochem. Engg., 24, 473-480 (2010).

Ju, X., X. Cao, Y. Sun, Z. Wang, C. Cao, J. Liu and J. Jiang: Purification and characterization of a fibrinolytic enzyme from Streptomyces sp. XZNUM 00004. World J. Microbiol. Biotechnol., 28, 2479-2486 (2012).

Kannel, W.B., P.A. Wolf, W.P. Castelli and R.B. D'Agostino: Fibrinogen and risk of cardiovascular disease-the Framingham study. JAMA. 258, 1183-1186 (1987).

Kapila, T., B.K. Bajaj, S. Kumar and N. Dilbaghi: Production, purification and characterization of fibrinolytic enzyme from Serratia sp. KG-21 using optimized media. 3 Biotech., 184, 1-15 (2017).

Khataee, A.R., M. Fathinia, S. Aber and M. Zarei: Optimization of photocatalytic treatment of dye solution on supported $\mathrm{TiO}_{2}$ nanoparticles by central composite design: Intermediates 
identification. J. Hazard. Mater., 181, 886-897 (2010).

Kim, S.B., D.W. Lee, C.I. Cheigh, E.A. Choe, S.J. Lee, Y.H. Hong, H.J. Choi and Y.R. Pyun: Purification and characterization of a fibrinolytic subtilisin-like protease of Bacillus subtilis TP-6 from an Indonesian fermented soybean, Tempeh. J. Ind. Microbiol. Biotechnol., 33, 436-444 (2006).

Kim, S.H. and N.S. Choi: Purification and characterization of subtilisin DJ-4 secreted by Bacillus sp. strain DJ-4 screened from DoenJang. Biosci. Biotechnol. Biochem., 64, 1722-1725 (2000).

Kim, H.C., B.S. Choi, K. Sapkota, S. Kim, H.J. Lee, J.C. Yoo and S.J. Kim: Purification and characterization of a novel, highly potent fibrinolytic enzyme from Paecilomyces tenuipes. Process. Biochem., 46, 1545-1553 (2011).

Ko, J.H., J.P. Yan, L. Zhu and Y.P. Qi: Identification of two novel fibrinolytic enzymes from Bacillus subtilis QK02. Comp. Biochem. Physiol. C. Toxicol. Pharmacol., 137, 65-74 (2004).

Lee, S.Y., J.S. Kim, J.E. Kim, K. Sapkota, M.H. Shen, S. Kim, H.S. Chun, J.C. Yoo, H.S. Choi, M.K. Kim and S.J. Kim: Purification and characterization of fibrinolytic enzyme from cultured mycelia of Armillaria mellea. Protein. Expr. Purif., 43, 10-17 (2005).

Lee, A.R., G.M. Kim,J.Y. Park, H.D. Jo, J. Cha, Y.S. Song, J. Chun and J.H. Kim: Characterization of a $27 \mathrm{kDa}$ fibrinolytic enzyme from Bacillus amyloliquefaciens $\mathrm{CH} 86-1$ isolated from Cheonggukjang. J. Korean Soc. Appl. Biol. Chem., 53, 56-61 (2010).

Lowry, O.H., N.J. Rosebrough, A.L. Farr and R.J. Randall: Protein measurement with the folin phenol reagent. J. Bio. Chem., 193, 265-275(1951).

Mahajan, P.M., S. Nayak and S.S. Lele: Fibrinolytic enzyme from newly isolated marine bacterium Bacillus subtilis ICTF-1: Media optimization, purification and characterization. J. Biosci. Bioeng., 113,307-314 (2012).

Mozaffarian, D., E.J. Benjamin, A.S. Go, D.K. Arnett, M.J. Blaha, M. Cushman and M.D. Huffman: Executive summary: Heart disease and stroke statistics-2015 update a report from the American heart association. Circulation, 131, 434-441 (2015).

Mukesh kumar, D.J., V. Premavathi, N. Govindarajan, M.D. Balakumaran and P.T. Kalaichelvan: Production and purification of alkaline protease from Bacillus sp. MPTK 712 isolation from dairy sludge. Global Veterinaria, 8, 433-439(2012).

Peng, Y., Q. Huang, R. Zhang and Y. Zhang: Purification and characterization of a fibrinolytic enzyme produced by Bacillus amyloliquefaciens DC-4 screened from douche, a traditional Chinese soybean food. J. Comp. Biochem. Physiol., 134, 45-52 (2003).

Peng, Y., X. Yang and Y. Zhang: Microbial fibrinolytic enzymes: An overview of source, production, properties, and thrombolytic activity in vivo. Appl. Microbiol. Biotechnol., 69, 126-132 (2005).

Ponnuswamy, V., A. Arumugaperumal, G.P.V. Samue, V.A. Mariadhas and A.A. Naif: Cow dung is a novel feedstock for fibrinolytic enzyme production from newly isolated Bacillus sp. IND7 and its application in in vitro clot lysis. Front. Microbiol., 7, 361 (2016). doi: 10.3389/fmicb.2016.00361

Rajesh, T.P., R.K.H. Mathan, S.R. Sekar and B. Anandaraj: Computational approach for the optimization of keratinase enzyme production from Bacillus cereus. J. Envinron. Biol., 37, 1473-1478 (2016).

Saravana kumar, K., A. Thiyagarajan and V. Kaviyarasan: Optimization of medium constituents for the production of extra cellular alkaline protease by Aspergillus fischeri using response surface experimental design. J. Biosci. Res., 1, 118-129 (2010).

Saxena, R. and R. Singh: Statistical optimization of conditions for protease production from Bacillus species. Acta. Biol. Szeged., 54, 135-141 (2010).

Simkhada, J.R., P. Mander, S.S. Cho and J.C. Yoo: A novel fibrinolytic protease from Streptomyces sp. CS684. Process Biochem., 45, 88-93 (2010).

Srinivas, M.R.S., N. Chand and B.K. Lonsane: Use of Plackett and Burman Design for rapid screening of several nitrogen sources, growth product promoters, minerals and enzyme inducers for the production of alpha-galactosidase by Aspergillus niger solid state fermentation system. Bioprocess. Eng., 10, 139-144 (1994).

Tamura, K., J. Dudley, M. Nei and S. Kumar: MEGA4: Molecular evolutionary genetics analysis (MEGA) software version 4.0. Mol. Biol. Evol., 24, 1596-1599 (2007).

Venkataraman, D., S. Ilangovan, M.V. Sampath kumar, M.J. Victoria, S.P.B.S. Pasha, S.B.R.K. Pandian and S. Gurunathan: Medium optimization and immobilization of purified fibrinolytic URAK from Bacillus cereus NK1 on PHB nanoparticles. Enzy. Microbial. Technol., 47, 297-304 (2010).

Vijayaraghavan, P. and S.G.P. Vincet: Statistical optimization of fibrinolytic enzyme production by Pseudoalteromonas sp. IND11 using cow dung substrate by response surface methodology. Springer Plus, 3, Article 60 (2014).

Wu, B., L. Wu, D. Chen, Z. Yang and M. Luo: Purification and characterization of a novel fibrinolytic protease from Fusarium sp. CPCC 480097. J. Ind. Microbiol. Biotechnol., 36, 451-459 (2009).

Wu, D., T. Ran, W. Wang and D. Xu: Structure of a thermostable serralysin from Serratia sp. FS14 at $1.1 \AA$ resolution. Acta Crystallogr. F Struct. Biol. Commun., 72, 10-15(2016).

Xiong, X., R.R. Ambati, Z. Cai and B. Lei: Purification and characterization of fibrinolytic enzyme from a bacterium isolated from soil. 3Biotech., 8, 90 (2018).

Yong, P., Q. Huang, Ren-huai Zhang and Yi. Zhang: Purification and characterization of a fibrinolytic enzyme produced by Bacillus amyloliquefaciens DC-4 screened from douchi, a traditional Chinese soybean food. J. Comp. Biochem. Physiol., 134, 45-52 (2003). 